DOI: $10.21767 / 2572-5432.100040$

\title{
Can Betatrophin be a New Biochemical Marker in the Diagnosis of Insulinoma?
}

\section{Suleyman Aydin}

Department of Medical Biochemistry and Clinical Biochemistry, Firat Hormones Research Group, Medical School, Firat University, 23119 Elazig, Turkey

Corresponding author: Aydin S, Department of Medical Biochemistry Firat Hormones Research Group, School of Medicine, Firat University, Elazig, Turkey, Tel: 90 5334934643; Fax: 90424 2379138; E-mail: saydin1@hotmail.com

Rec date: Mar 07, 2017; Acc Date: Mar 10, 2017; Pub date: Mar 14, 2017

Copyright: (c) 2017 Aydin S. This is an open-access article distributed under the terms of the Creative Commons Attribution License, which permits unrestricted use, distribution, and reproduction in any medium, provided the original author and source are credited.

Citation Aydin S (2017) Can Betatrophin be a New Biochemical Marker in the Diagnosis of Insulinoma? J Clin Mol Endocrinol 2: e101.

\section{Editorial}

Originating from the $\beta$ cells of Langerhans islets, insulinoma has an incidence of 1 to 4 in one million in the general population, but is the most common tumor among pancreatic neuroendocrine tumors [1]. It can be life-threatening depending on the presence of hypoglycemia. It is diagnosed through clinical [anxiety, nervousness, tremor, sweating, feeling of hunger, palpitation, restlessness, angina, and especially the presence of the Whipple triad (hypoglycemia symptoms + low blood sugar + the disappearance of symptoms upon glucose intake)] and laboratory findings. Radiological imaging is helpful in distinctive diagnosis and determination of the operation procedure. Insulinoma diagnosis is supported by $C$ peptide $>0.6 \mathrm{ng} / \mathrm{ml}$, insulin $>3 \mu \mathrm{lU} / \mathrm{mL}$, proinsulin $>5 \mathrm{pmol} / \mathrm{L}$, simultaneously with hypoglycemia (plasma glucose $<55 \mathrm{mg} / \mathrm{dl}$ ) $[1,2]$.

It is suggested in this editorial that measuring plasma concentrations of betatrophin [3], in addition to the classical parameters used to detect insulinoma through biochemistry, can help diagnosis. Insulinoma originates from the $\beta$ cells of Langerhans islets [1]. Betatrophin, released primarily from the liver and adipose tissue, stimulates insulin secretion from $\beta$ cells of Langerhans islets, increases cell proliferation and additionally, improves glucose tolerance [3]. Therefore, theoretically, it is expected that more betatrophin is secreted in insulinoma, and this can help in the distinctive diagnosis of insulinoma. Besides, with the physiological and biochemical qualities noted above, betatrophin may be promising in the treatment of type 1 and type 2 diabetes patients.

When insulinoma is suspected, analyzing plasma betatrophin levels may help reduce the rate of false positive and false negative results. If plasma betatrophin analysis can become established as a new distinctive parameter in insulinoma diagnosis, the need for using expensive imaging methods for diagnosing insulinoma will be reduced. The accuracy rate of abdominal computerized tomography (CT) with oral contrast used to define the tumor location and number and to evaluate metastases ranges from 35 to $85 \%$. Consequently, plasma betatrophin analysis is believed to have a potential role in diagnosis, when insulinoma is suspected [4]

\section{References}

1. Okabayashi T, Shima Y, Sumiyoshi T, Kozuki A, Ito S, et al. (2013) Diagnosis and management of insulinoma. J Gastroenterol 19: 829-837.

2. Rostambeigi N, Thompson GB (2009) What should be done in an operating room when an insulinoma cannot be found? Clin Endocrinol (Oxf) 70: 512-515.

3. Yi P1, Park JS, Melton DA (2013) Betatrophin: a hormone that controls pancreatic $\left.\right|^{2}$ cell proliferation. Cell 153: 747-758.

4. Griffeth LK (2005) Use of PET/CT scanning in cancer patients: technical and practical considerations. Proc (Bayl Univ Med Cent) 18: 321-330. 